JELTL (Journal of English Language Teaching and Linguistics) e-ISSN: 2502-6062, p-ISSN: 2503-1848

2018, Vol. 3 (1)

www.jeltl.org

\title{
Aspects of Feminist Writing: A Presentation of Common Issues
}

\author{
${ }^{1}$ Dr. Meenakshi Sharma Yadav \\ Girls Community College \\ King Khalid University, Kingdom of Saudi Arabia \\ e-mail:kkudrmeenakshi@gmail.com \& urdrmeenakshisyadav@gmail.com \\ ${ }^{2}$ Dr. Manoj Kumar Yadav \\ Faculty of Languages \& Translation \\ King Khalid University, Kingdom of Saudi Arabia \\ e-mail:kkudrmanoj@gmail.com \& rudrmanojyadav@gmail.com
}

\begin{abstract}
Feminist literary criticism is a literary criticism knowledgeable by feminist theory, or, more broadly, by the politics of feminism. It uses feminist principles and ideology to critique the language of literature. This school of thought seeks to analyze and describe the ways in which literature portrays the narratives of male domination by exploring the economic, social, political, and psychological forces embedded within literature. Feminism emerged as an important force in the western world in the 1960s when women realized the attitude of their male colleagues who swore about equality, was actually the strategy used by them to keep women subservient, then a revolution by women to fight against them, and against racism and sexism was felt. This awakening spread over and as a result, feminist criticism emerged on as an offshoot of women's Liberation Movement. Beginning with the interrogation of malecentric literature that portrayed women in a demeaning and oppressed model, theorist such as Marry Ellman, Kate Millet, and Germaine Greer challenged past imaginations of the feminine within literary scholarship. It is very important for us to know that who these women writers are, what did they write and what were the sources of their writings. The present paper focuses on some of the above said important aspects of feminist writings and some of the famous feminist writers also. Keywords: Subservient, Second Wave Feminism, Stereotype, Pseudonym, Existentialist, Vindication, Sovereignty, Misogyny, androgyny
\end{abstract}




\section{INTRODUCTION}

Feminist literary criticism can be traced back to medieval times. Some critics argue that Geoffrey Chaucer's Wife of Bath could be an example of this. While the beginning of "proper" feminist literary criticism is typically considered during second-wave feminism, there are multiple texts prior to this era that contributed greatly to the field. Though Feminist literature and feminist literary criticism came into existence in the middle of the twentieth century, the seeds were sown in the eighteenth century. It was Mary Wollstonecraft who wrote a book, A Vindication of the Rights of Women in 1792, in which she argues that women are not naturally inferior to men, but appear to be only because they lack education. Virginia Woolf's A Room of One's Own (1929) is undoubtedly one of the formative feminist texts and is noted in its argument for both a literal and figural space for women writers within a literary tradition dominated by men. In an essay Elaine Showalter Towards a Feminist Poetics (1979), she speaks for feminist criticism and puts her views that it has sub-divisions which are basically concerned with 'woman as reader' and 'woman as a writer'. She has categorized the woman as a reader as feminist critique and woman as a writer as gynocritics.

The present paper in its context speaks about some female writers, the feminist view of discussion in their writings and their place in literary writings either they are written by male writers and female writers. The writings of female authors give perfect insight into their place the ideology - ridden literary history and reinforce cultural conflicts from the class of civilizations. Does the writer refuse to take on women's issues and instead write under a male pen name and use male values? Calling George Eliot! Was she embroiled in early feminism and trying to prove that her voice and her writing were just as legit as Virginia Woolf did? Or does she adopt a more post-feminism approach and simply assume that her work deserves to be heard? All of these approaches give plenty of food for thought as to what kind of world our author lived in. For example, Sandra Gilbert and Susan Gubar's The Madwoman in the Attic argues that Rochester's mad wife who was cooped up in his attic symbolizes the inability of women to get their creative juices going. Instead, they had to resort to being destructive. Who can blame them?

\subsection{Research Problem}

In today's cross-cultural communication world, it is hard to imagine a lifestyle that excludes female rights. Of course, we are all aware that some issues with feminism are present even in the contemporary time. There are certain countries that have not yet set out the rules for a life with equal standards. The life of a woman used to be a challenging venture filled with uphill battles. There were no options for a different approach to life or unique perception of duties.

Modern times have awoken the new concepts and better ideas in order to change everything about the inequality of the genders. Feminism became the recalcitrant, rebellion and persistent source that created a revolution in thinking in the common - communication world. Writing this research paper about aspects of feminist writing is quite a difficult and challenging task, but it is also a rewarding 
venture into history. The study of feminist writings has various aspects to access them as before studying it should be clear about feminism, feminist writings, feminist literary criticism, and what they thrashed out.

\subsection{Objectives of the Study}

The main objective of this study is to highlight the specific features of feminism, leading feminist writers, and important historical phases of feminist writings. The paper has the set up with a small discussion of keywords and features of feminism and feminist literary criticism. The study is being done in a logical order as it tells some facts, the role of some feminist critics in literary criticism, analysis of some feminist writers and the new words which are produced by them.

\section{REVIEW OF LITERATURE}

In the present paper, I review and critically reflect on the key terms and features of the feminist writings that are understood and discussed in the literature. Feminist theory focuses on empowering women and helping them discover how to break the stereotypes and molds of some traditional roles and roots that women play that may be blocking their development and growth. This type of therapy grew out of influences of the women's movement of the late 1960's. Feminist theory tends to be more focused on strengthening women in areas such as assertiveness, communication, relationships, and self-esteem. One of the main goals of feminist therapists is to develop equal mutual relationships of caring and support. The therapist believes that her client is the only "expert" in her own issues and will help her develop the tools and personal property needed to reach her potential as a unique and valuable individual.

\section{RESEARCH METHODS}

Research methods are the tools used to investigate, examine and analyze the social world (e.g., interviews, observations, questionnaires). There is not a clear definition of feminist methodology, in part because this is contested in the literature.

There is a debate over what feminist methodology is, and whether is it exists? Chafetz (2004) argues that there is no such thing as a feminist methodology and that we should use all and any research tool necessary to further our research on gender / women. In contrast, Baber (2004) argues that there is such a thing as feminist methodology and that some research tools are not useful for feminist research. Baber (2004) argues that feminist methodology is distinct in its assumptions and its goal to make women's lives better. Undoubtedly, feminist methods privilege women's experience. Privileging women's experiences is a response to these experiences being silenced and misconstrued. Just focusing on women, however, doesn't ensure that women being researched will have power in the research process. However, specific methods have been developed for carrying out feminist research.

\section{HISTORICAL PHASES OF FEMINIST WRITING}

The term feminism can be used to describe a political, cultural or economic movement aimed at establishing equal rights and legal protection for women. 
Feminism involves political and sociological theories and philosophies concerned with issues of gender difference, as well as a movement that advocates gender equality for women and campaigns for women's rights and interests. Although the terms "feminism" and "feminist" did not gain widespread use until the 1970s, they were already being used in the public parlance much earlier; for instance, Katherine Hepburn speaks of the "feminist movement" in the 1942 film 'Woman of the Year'.

Feminists and scholars have divided the movement's history into three waves. The first wave refers mainly to women's suffrage movements of the nineteenth and early twentieth century (mainly concerned with women's right to vote). The second wave refers to the ideas and actions associated with the women's liberation movement beginning in the 1960s (which campaigned for legal and social rights for women). The third wave refers to a continuation of, and a reaction to the perceived failures of, second-wave feminism, beginning in the 1990s -

\section{First Wave Feminism: Men's Treatment of Women}

In this early stage of feminist criticism, critics consider male novelists' demeaning treatment or marginalization of female characters. First wave feminist criticism includes books like Marry Ellman's Thinking About Women (1968), Kate Millet's Sexual Politics (1969), and Germaine Greer's The Female Eunuch (1970). An example of first wave feminist literary analysis would be a critique of William Shakespeare's Taming of the Shrew for Petruchio's abuse of Katherina.

\section{Second Wave Feminism: Gynocriticism}

Elaine Showalter pioneered gynocriticism with her book A Literature of Their Own (1977). Gynocriticism involves three major aspects-

- The first is the examination of female writers and their place in literary history.

- The second is the consideration of the treatment of female characters in books by both male and female writers.

- The third and most important aspect of gynocriticism is the discovery and exploration of a canon of literature written by women; gynocriticism seeks to appropriate a female literary tradition.

3. Third -Wave Feminism: Third- Wave feminism encompasses several diverse strains of feminist activity and study. Rebecca Walker quoted the term "Third Wave" to highlight the focus on queer and non-white women.

\section{WOMEN AS READERS AND WRITERS}

In the essay by Elaine Showalter Towards a Feminist Poetics, she does the talk of woman readers and writers, but this essay has not well answered the questions like do woman read and write differently? Elaine Showalter a forerunner among feminist literary critics has tried to answer these basic questions. Women 
before always read what was written by male writers. Feminists have claimed that the literature and literary criticism bears a stamp of male domination. Women were thought to be merely showpieces, they were the symbol of weakness. They always read what was written by male writers before. Men have depicted women in their literary works and they have also evaluated women writers. According to Elaine Showalter, one of the problems to the feminist critique is that it is male-oriented. When the need of female writers was felt, the woman started writing. As Elaine Showalter explains it:

"It was through the women's liberation movement that we began to draw connections between over own work and our lives, to note the disparities between the identifications and ambitions that these attracted us, along with thousands of other women to study and teaching of literature and the limited and secondary roles women granted to female scholars..........Feminism spoke to our lives and our literary experience with the fierce urgency of a revelation or a Great Awakening. (Showalter 1985 .5)

\section{WOMAN WRITERS AS GYNOCRITICS}

Elaine Showalter has suggested the term 'gynocritics' for a woman as writers which have been adopted by her form of the French term ' la gynocriticism'(Sethuraman 404). The major portion of both literature and literary criticism has been written from the male point of view. Female writers in the urge to re-write the man story as her story has come forward. According to Sarla Palkar in her article Feminist Literary Theory creating New Maps, by the late 60s and 70s feminism emerged as an important political force in the Western Word. As the early feminist writers were mainly concerned with social and political change, little attention was paid to literature and literary criticism at the initial stage of the women's movement, (Women's Writing 13). Many of the literary abstractions which were claimed to be universal have in fact been described by male perceptions and options. According to Elaine Showalter, In its earlier years, feminist criticism concentrated on exposing the misogyny of literary practice: the stereotyped images of women in literature as angels or monsters, the literary abuses or textual harassment of women from literary history, (The New Feminist Criticism 5).

\section{ROLE OF FEMINIST CRITICS IN LITERARY CRITICISM}

Women were rarely presented as women and realistically. They were either portrayed as selfless, sacrificing, complaint angels which were symbols of beauty and purity or she was portrayed as villain and victimizer which was a symbol of monster. Women characters were given no positive role even as the house makers. Such misinterpretations, literary abuse and textual harassment of women in literature are exposed by feminist critics.

Elaine Showalter commenting on women's writing says that women writers had a literature of their own, whose historical and thematic coherence as well as artistic importance was obscured by the patriarchal values that dominate our culture. She, in her book Literature of Their Own (1977), calls women's writing a subculture. 
Women writers popular in their lifetime seem to vanish without a trace from the records of prosperity. She traces the evolution of their subculture from times of Brontes since 1830 to the present day. The development is outlined by her in three phases or stages which are the feminine, feminist and female phrase. She discovers three major phases of historical development which she claims to the common to all literary movements,

"First, there is a prolonged phase of imitation of the prevailing modes of the dominant tradition, and internalization of its standards of art and its views on social roles. Second, there is a phase of protest against these standards and values, including a demand for autonomy. Finally, there is a phase of self - discovery, a turning inward freed from some of the dependency of opposition, a search for identity. An appropriate terminology for women writers is to call these stages, feminine, feminist and female. (Showalter 1977, 13)

\section{SOURCE OF WOMEN'S WRITING}

When we talk of women writers and readers we come upon questions like what was the source of women's writing? What did they write, why did they write and if she wrote what did she write about? What were the conditions? Under which come up is that, what was the response to their writings; well now when we look at these questions we find that women wrote across every existing genre. The primary sources of women's writing were letters and journals. Men had much more freedom of movement, the mobility of women was restricted and there were reasons for these restrictions which were that they did not have money to travel or if they had they were not allowed to move about dependently and therefore letter was one of the few means of communicating and was an important link to experience beyond the 'here and now'.

According to 'Dale Spender' in an introductory chapter of A Vindication of the Rights of Woman in the eighteenth century, women started writing autobiographies and biographies, plays and novels, and criticism. During this period, women also started writing as literary critics. Deprived of formal education, denied professional occupation and increasingly confined to the domestic spheres like a human-animal in the seventeenth and eighteenth centuries many females sought knowledge of the world and the intellectual stimulation and they frequently thought themselves to read and write. This was an age where there was a dramatic increase in the size of female reading public and in the number of female writers. The more women readers there were the women writers were required and more the women writers emerged more women readers they were. According to Elaine Showalter, women to their contemporaries, the nineteenth-century women writers were women first and writers second. A women novelist unless she disguised herself with a pseudonym had to expect critics to focus on her feminist and rank her with the other women writers of her day, no matter how diverse their subjects or styles, (Showalter 1977 1). 


\section{THE PURPOSE OF WRITING FOR WOMEN WRITERS}

There were some enlightened issues which were raised in contemporary times according to which why women read novels, what did they read, what did they get from them, with whom they shared their experiences? Women's relationship to the novel as writers, readers and critics and some of the contributions are discussed here. Women wrote for business, for pleasure and also wrote for many reasons that man wrote. Sarah Fielding welcomed every penny she earned. Charlotte Smith wrote to support her children. Charlotte Lennox wrote as she was under the financial burden and had left her husband. Women wrote as they found the opportunity to write, but peeping beside these basic reasons for seeking employment women also wrote because they needed to find a form of self-expression to realize their potential and to define their own lives. They needed their own voice. Now the point is what did they write about? Basically, they wrote about ordinary women's lives, they were concerned with fiction, politics etc. The women writers wrote about the world, but they did so from women's perspective, the objects and events of the world pass through different filter priorities, perceptions, protests in the work of women. They used fiction to explore their own world and to remedy some of the deficiencies of their exclusion and isolation.

Many seventeenth and eighteenth-century women writers wrote in psychological circumstances, many women writers wrote without 'a room of their own'. Despite these limitations, they played a crucial part in shaping and extending and securing the viability of a literary community and their contribution deserves to be much better appreciated and widely known. Women's efforts were rarely welcomed by the literary establishment. Mary Wollstonecraft insisted that one of the last male bastions to fall would be that which appropriated for men intellectuality and creating while enormous material and legal gains have been made in two hundred years since she presented her case in The Vindication of the Rights of Woman.

Elaine Showalter while is commenting on the way of a feminist critique might precede she talks of a well-known example of the opening part of Thomas Hardy's The Mayor of Casterbridge, which has been praised by Irving Howe who has appreciated the brilliance and power of this opening scene: To shake loose from one's life to discard that dropping rag of woman, with her mute complaints and maddening passivity to escape not by slinking abandonment but through the public sale of her body to a stranger, as horses are solid at a flair and thus to wrest, through sheer a moral willfulness, a second choice out of life it is with stroke, so insidiously attractive to male fantasy, that The Mayor of Casterbridge begins. (Indian Women Novelist 66)

How like other male critics of Hardy has conveniently overlooked in the novel that Henchard not only sells his wife but also his child who can only be female. Henchard is symbolically selling his entire share in the world of women, though he was served with the bond with the female community. Hardy has shown man at his best and thus female characters in 'The Mayor of Casterbridge' are somewhat 
idealized and melancholy projections of a repressed male self. (Indian Women Novelist 66)

\section{VIEWS OF SOME FEMINIST WRITERS}

Feminism has no apt and suitable definition. In the west, it is treated as an offshoot of Marxism which existed in the capitalist countries as a defensive body of orthodoxy surrounded by protective walls, encrusted with fear, terror, brittle and bitterness acting with disillusionment.

Elaine Showalter advocates a reading of Woolf which is detached from the narrative strategies she employs. She accepts Virginia Woolf's historical and representative importance. Feminist critics were always fascinated by Virginia Woolf and they found her much of her time in thinking about women. Virginia Woolf wrote in1929: It is obvious from the values of women differ very often from the values which have been made by the other sex. (Indian Women Novelist 66). Elaine Showalter has also talked of the criticism by Woolf on androgyny, she in her book A Literature of Their Own in an article, Virginia Woolf and the flight into Androgyny' says that Woolf's idea about women's literature was loosely connected to her personal struggle for self-definition. In the 1918, an anonymous interview of R. Brimley Johnson's The Women Novelists, Woolf expressed her dissatisfaction with the feminine novelists who wrote under the tyranny of what was expected from their sex, and the feminist novelists, the women who wish to be taken off for women, (Showalter 1977, 280).Woolf has raised some of the problems that she dealt with in A Room of One's Own. She argues that women writers can only be successful if they are financially independent. Whether this is true and how this might have affected the development of a female literary canon is a perfect way to bring the feminist perspective to literature. Much of Woolf's writing at this point was concerned with the external difficulties and obstacles of the women writers, an emphasis connected to her own struggle to find a voice.

The Seventies and Eighties saw a spurt in feminist writing which condenses in its pages the lived range of the exploited female against male dominion that characterizes both Western and Eastern patriarchal cultures. Such work presented women as expressed, exploited, tortured, and cheated, angry, alienated and rebellious. Most of the negative criticism tried to justify the assumption that made novels by women would be recognizably inferior to those by men, when the Victorian thought of the female body and its presumed afflictions and liabilities. First, because of the biological creativity of childbirth seemed to them directly to rival the aesthetic creativity of writing. Secondly, there was a strong belief that the female body was in it an inferior instrument, small weak and in Geraldine Jewsbury's word, liable to collapses, eclipses, and failures of power.... Unfitting her for the steady stream of ever-recurring work. (Showalter 1977, 77).

Victorian women were taught to keep private diaries (such as Mrs. Gaskell's diary about her child Marianne) or to share them in intimate friendship with one or two women. There were strong taboos against sharing with men. Dale Spender edited a book on early British Women writers and in the introduction of $A$ 
Vindication of the Right of Woman, writing has talked of the changes which took place in the eighteenth century.

Women started writing and became soon creative writers and academicians who started questioning about the deception of women in literature and were concerned with the excitement of violating existing sexist paradigms. Some pioneering works that stimulated this movement are Virginia Woolf's A Room of One's Own (1927), Simone de Beauvoir's The Second Sex (1949), Mary Ellmann's Thinking About Women (1968) and Kate Millet's Sexual Politics (1968).

Simone de Beauvoir: French writer Simone de Beauvoir laid the foundation for the modern feminist movement is known for The Second Sex, a detailed analysis of women's oppression and a foundational tract of contemporary feminism, written in 1949. As an existentialist, she accepted Jean-Paul Sartre's precept existence precedes essence; hence one is not born a woman, but becomes one. De Beauvoir introduces her text by asking the question, what is the woman? She then goes on to explain that man is considered the default, while a woman is considered the "Other". Thus humanity is male, man defines woman not herself but as relative to him, but the only earthly destiny reserved to the woman equal, child -woman, soul sister, woman-sex, and a female animal is always man.

She argues women have historically been considered deviant and abnormal and contends that even Mary Wollstonecraft considered men to be the ideal toward which women should aspire. De Beauvoir argues that for feminism to move forward, this attitude must be set aside. Her main argument was that women have always been thought to be treated as an object for men. They were denied individuality and responsibility. These assumptions dominate social, political and cultural life to such an extent that women have come to believe in them, accept them in real life. Thus women become what they do because society expects them to be. Her arguments were generally accepted by all, but British feminist criticism, in particular, is more immersed in Marxist Ideology. Besides gender, the class also became a preoccupation in literary studies.

Toril Moi: R.K. Dhawan's book on Indian Women Novelists in set.1:vol.1 talks of Toril Moi, Mary Ellmann, and Kate Millet. Toril Moi formulates a positive approach to Woolf's famous concept of androgyny which to Showalter is a fight from fixed gender. Toril Moi has used the term Post-Feminism, to cover the different configurations of Feminism and Post - Feminism today, (Shawan 59). Jardine herself offers a definition of feminism; she writes, feminism is generally understood as a movement from the point of view of by and for women, (Indian Women Novelist 59). Jardine's views of feminism as a movement by which women takes a different and very specific form in different contexts. In Jardine's central neologism genesis there is an interesting contradiction between her rejections of labels and definitions by naming her own textual discovery. 
Mary Wollstonecraft: Mary Wollstonecraft commenting on Rousseau's theory in Vindication of the Rights of Woman, (1792) which was actually based on the discriminating attitude and aimed at subjugating women to male desire. She writes, I, therefore, will venture to assert that till women are more rationally educated, the progress of human virtue and improvement in knowledge must receive continual checks, (Vindication 45). She showed a clear sense of women's role and responsibilities as mothers. Cady Stanton argued in 1869 that because man and woman are the compliment to one another we need woman's thought in national affairs to make a safe and stable government and later in 1982 insisted on women's right to her birthright to self-sovereignty (Dhawan 63). The Anglo American feminist tradition, however, advocated the individualist thought as the only politically correct form till as recently as the 1970s. This strand placed political priority on enactment of the equal rights amendments and on demolishing the gender-stratified educational system and the economy that disadvantaged women through occupational segregation.

In present feminism is historically significant that is historically specific movement rooted in French Enlightenment Thought (Mary Wollstonecraft) and in British Liberalism (John Stuart Mill). Elaine Showalter presents a feminist gallery alongside her pioneering work of practical criticism; she has also significantly contributed towards giving some theoretical base of feminist thinking and is therefore grouped with other theorists like Annette Kolodray and Myra Jehlem. The other type of feminist literary criticism is the examination of existing criticism on women writers mainly by male critics. Some commentators feel that the issue of men's relationship to feminism should be addressed and with the publication of men in feminism edited by Alice Jardine and Paul Smith (1987), it is a subject insistently out in open.

Kate Millet and Mary Ellmann: Writers like Kate Millet and Mary Ellmann wrote on the critique of male discourse or on the representation of women by men and they dealt with women as readers, similarly feminist critics like Elaine Showalter, Sandra Gilbert, and Susan Gubar dealt with women's self representation which focuses its attention on the subject of women as writers. Mary Ellmann argues in her book Thinking About Women (1968) that western culture employs a very obsolete and ridiculous sexual mode of thought and discuss the insidious effect of thinking by sexual analogy. It is generally believed that women as readers, critics or writers can always be weak and passive whereas man is always strong and active. Kate Millets's Sexual Politics (1968) can be regarded as a first major book in the U.S.A. It is characteristically a combination of detailed analysis of literary works and political argument. She distinguishes sex from gender; sex is biological whereas gender is a cultural construct.

In the late 1970s, three major studies on women writers were published which tried to reconstruct a female literary tradition in British and American literature and history: Ellen Moer's Literary Women (1976), Elaine Showalter's A Literature of Their Own, (1977), and Sandra Gilbert and Susan Gubar's The 
Madwoman in the Attic, (1979). These books were the major studies on women writers. They are now the modern classics of the feminist approach to literature.

\section{INDIAN FEMINIST WRITERS}

Indian women writers constitute a major segment of the contemporary Indian writing in English. Even Indian women like western feminist writers suffered oppression and injustice at the hands of the male. Indian English Literature has come of age. The women novelists also in India constitute a major group of Indian writers. R.K. Dhawan in his book, Indian Women Novelists, focuses on women's issues, they have a women's perspective on the world, (Dhawan 10). He further writes that one of the reasons that women in India have in large number taken up their pen because it has allowed them to create their own world. It has allowed them to set the conditions of existence, free from the direct interference of men, (11). Indian women writers including Nayantara Sahagal, Shashi Desh Pande, and Shobha De, have dealt with issues related to women.

In India too, the study of feminism, the study of the images of women in literature is one of the earliest fields of feminist literary criticism to be explored. Literary criticism in India deals with the portrayal, treatment, and images of women as seen in the works of particular Indian authors, both male and female. The treatment of women by Nayantara Sahagal, the image of women as reflected in Indian writings are some of the titles of dissertations submitted to the Mother Teresa Women's University, Kodaikanal. Sushila Singh in her, Recent Trends in Feminist Thought: A Tour de Horizon, in a book edited by R.K. Dhawan writes that Gayatri Spivak has made an admirable effort to develop a materialist anti-imperialist feminism which draws on the insights of recent poststructuralist and postmodern theory ..... Does not leave high theory of men. She takes over for her own feminist and anti-imperialist purposes, (62). Women writers are enjoying an increasing popularity and prestige. They have impressive records of success. Chaman Nahal in his Feminism in Indian English Fiction, his article in a book edited by R.K. Dhawan says, if I take into account Simone de Beauvoir's The Second Sex or some of the other French writers, they are very much concerned about the physical suppression of women. Therefore, according to the French models of feminism, it would imply greater sexual expression. If we take into account the British models, all feminists slowly become respectable or reclaimed into the male world order. If we consider American models they are more outspoken, (28).

Feminist criticism has also come under fire from some of its own branches. According to Sudha Pandya in her article on 'feminist critical theory in the book 'Indian Women Novelists' writes that 'it can be asserted as hitherto -sexist, homophobic, racist or guilty of, cultural imperialism.....black feminist critics, on the other hand, believes they have suffered from the 'racism' of white feminist theory'(82). Considering the fact that there are all these various strands within feminist criticism, it is understandable and probably welcome that it has not arrived at any one theory, acceptable to all. 


\section{CONCLUSION}

In the 1980's, feminism emerges as a thought system, a point of view to reorganizing the world realities, a positive holistic approach to life, a step forward sanity in human relationship, and perhaps the only mode for the preservation of very human existence in this planet. Elaine Showalter in her essay, Towards a Feminist Poetics, in the end says that, the task of feminist critics is to find a new language, a new way of reading that can integrate our intelligence and our experience, our reason and our suffering, our skepticism and our vision, (142). Further, she says feminist criticism is not visiting. It is here to stay and we must make it a permanent home, (142). Elaine Showalter has talked about the aspects of feminist writings in her essay Towards a Feminist Poetics and has very well expressed rather placed her stand in the aspects of feminist writings.

\section{REFERENCES}

Dhawan, R.k.(ed), Indian Women Novelist. Set .1:vol.1. New Delhi: Prestige Books, 1991.

Ghadially, Rehana.(ed), Women in Indian Society: A Reader. New Delhi: Saga, 1988.

Jain, Jasbir,(ed), Women's Writing, Text, and Context. Jaipur /New Delhi: Rawat Publications, 1996.

Nahal, Chaman. "Feminism in Indian English Fiction," in book Indian Women Novelist. Set. 1: Vol.1.ed R .k. Dhawan. New Delhi: Prestige Books, 1991.

Sethuraman, V.S. (ed), Contemporary Criticism, An Anthology. Madras: MacMillan, 1989.

Showalter, Elaine. A Literature of Their Own: British Women Novelist from Bronte to Lessing. N.J: Princeton University Press, 1977.

Showalter, Elaine. (ed), The New Feminist Criticism Essay on Women Literature and Theory. NJ: Pantheon Books, 1985.

Singh, Sushila. "Recent Trends in Feminist Thought: A tour de Horizon" in book Indian Women Novelist.ed R.K. Dhawan, N. Delhi: Prestige Books,1991.

Spender, Dale. (ed), Living By the Pen Early British Women Writer.NY/ London: Teacher College Press, 1992.

Wollstone Craft, Mary. "A Vindication of Rights of Women" in A Vindication of Rights of Women and The Subjection of Women by Mary Wollstonecraft and John Stuart Mill. London: London: J.M Dent and co. (1929) 1989 